\title{
Uttarakhand's Demographic and Health Profile: A Scoping Review with Implications for Research
}

Seth $\mathbf{K}^{*}$
Department of Public Health Open Access, New Delhi, India

*Corresponding author: Katyayni seth, Department of Public Health Open Access, New Delhi, India, Tel: 9582180912, E-mail: skatyayni@gmail.com

\section{Review Article}

Volume 1 Issue 1

Received Date: May 30, 2017

Published Date: June 09, 2017

DOI: $10.23880 /$ phoa-16000106

\section{Abstract}

With one of the lowest population densities among states in India and 70 percent of its area covered by forests, Uttarakhand is one of the most remote states in the country. This study analyzes district-level changes that have occurred in Uttarakhand's demographic and health profile since the formation of the state in 2000. It addition, via a scoping review, it assesses the state of the literature on the implementation and impact of two major health programs initiated by the government to improve health outcomes in the state, the National Rural Health Mission and Rashtriya Swastha Bima Yojana. It concludes that there is scant, state-wide information available on the implementation of these programs and suggests linking research efforts with program monitoring arrangements in order to bridge gaps in knowledge. This review article will be useful to researchers and policy makers interested in understanding the demographic and health changes that have occurred in Uttarakhand since its formation and gaps that remain in the literature on health services in the state.

Keywords: Uttarakhand; Demographic profile; Scoping review; NRHM; RSBY

\section{Introduction}

Uttarakhand was formed through the bifurcation of India's largest state, Uttar Pradesh, in 2000. It is a relatively small state, ranking 19 th and 20 th amongst the 28 states of India in terms of territory and population, respectively [1]. The purpose of this study on Uttarakhand is twofold. First, it uses publicly-available data sources to construct the demographic and health profile of the state. For this purpose, it collates information from multiple rounds of the national census and health surveys conducted by public authorities and non-governmental organizations. The latter include government of India's National Family Health Surveys and Annual Health Surveys, and UNICEF's 2009 Coverage Evaluation Survey. Secondly, in order to examine the nature of research being conducted on health services in
Uttarakhand, this study presents findings from a scoping review focusing on two health programs, the National Rural Health Mission (NRHM) and Rashtriya Swasthya Bima Yojana (RSBY). This review summarizes the literature available on the implementation of these programs and their impact on health outcomes in the state. Thus, this article both contextualizes and summarizes research on two of the largest public health programs in Uttarakhand for the benefit of researchers and policymakers. In doing so, it highlights gaps in the existing literature on improving access to quality health services in the state through government funded and implemented programs. This article is structured as followed: section one details demographic changes that have occurred in the state between the 2001 and 2011 censuses. It focuses on population growth and its links to urbanization, gender distribution across the state, and 
migration within the state. Section two discusses changes in the state's health profile by detailing maternal and child health, and prevalence of nutritional deficiencies and chronic diseases. Section three collates information on the implementation of NRHM and RSBY programs in the state. Finally, the implications of these findings for research and policy are discussed in the conclusion.

\section{Demographic Profile of Uttarakhand}

\section{Population Growth and Urbanization}

Uttarakhand is one of India's most remote states. Located on the southern slopes of the Himalayan mountain range, it occupies a largely mountainous region and forests cover up to 70 percent of its area [2]. As (Table 1) highlights, most of Uttarakhand is sparsely populated; based on the 2011 census, population densities in ten of the state's thirteen administrative districts fall well below the national average of 382 people per square kilometre.

\begin{tabular}{|c|c|c|c|}
\hline S. no & District & Population density, 2011 (per sq. km.) & Rank amongst districts in India* \\
\hline 1 & Uttarkashi & 41 & 21 \\
\hline 2 & Chamoli & 49 & 26 \\
\hline 3 & Pithoragarh & 69 & 32 \\
\hline 4 & Bageshwar & 116 & 56 \\
\hline 5 & Rudraprayag & 119 & 58 \\
\hline 6 & Pauri & 129 & 61 \\
\hline 7 & Champawat & 147 & 69 \\
\hline 8 & Tehri & 169 & 106 \\
\hline 9 & Almora & 198 & 126 \\
\hline 10 & Nainital & 225 & 285 \\
\hline 11 & Dehradun & 550 & 317 \\
\hline 12 & Udham Singh Nagar & 648 & 364 \\
\hline 13 & Haridwar & 817 & - \\
\hline \multicolumn{3}{|c|}{ UTTARAKHAND } & 189 \\
\hline \multicolumn{4}{|c|}{ Source: Census 2011[1] } \\
\hline
\end{tabular}

Table 1: Population densities in districts of Uttarakhand, 2011.

Uttarakhand's population is concentrated in its four most urbanized districts. These are located in the plains covering the southern and western parts of the state. In 2011, these districts - namely, Haridwar, Nainital, Udham Singh Nagar and Dehradun-housed 61 percent of the state's total population, including 85 percent of its urban and 51 percent of its rural population [1]. Between 2001 and 2011, the population of these districts grew by 31 percent: the urban population by 27 percent and the rural population by 23 percent. This contrasts sharply with demographic changes in the rest of Uttarakhand. Population in the nine remaining districts-referred to as the hill districts in this paper-is either growing at a substantially slower pace or declining. Between 2001 and 2011, the number of people residing in Uttarakhand's hill districts increased by only four percent, with the urban and rural populations increase by two percent each. The number of people living in the districts of Almora and Pauri Garhwal actually shrank by 1.3 and 1.4 percent, respectively. In both districts, this decline was driven by reductions in the number of rural inhabitants, with urban areas experiencing an increase in their populations $[3,4]$. (Table 2) lists district-level changes in Uttarakhand's population between 2001 and 2011. 


\begin{tabular}{|c|c|c|c|c|c|c|}
\hline Districts & $\begin{array}{c}\text { Total } \\
\text { population } \\
\mathbf{2 0 1 1}\end{array}$ & $\begin{array}{c}\text { Share of } \\
\text { UK's 2011 } \\
\text { population } \\
\mathbf{( \% )}\end{array}$ & $\begin{array}{c}\text { Increase in } \\
\text { population } \\
\mathbf{2 0 0 1 - 2 0 1 1} \\
\mathbf{( \% )}\end{array}$ & $\begin{array}{c}\text { Urban } \\
\text { population } \\
\mathbf{2 0 1 1} \mathbf{\% )}\end{array}$ & $\begin{array}{c}\text { Change in } \\
\text { urban } \\
\text { population } \\
\mathbf{2 0 0 1 - 2 0 1 1} \\
\mathbf{( \% )}\end{array}$ & $\begin{array}{c}\text { Change in } \\
\text { rural } \\
\text { population } \\
\mathbf{2 0 0 1 - 2 0 1 1} \\
\mathbf{( \% )}\end{array}$ \\
\hline PLAIN DISTRICTS & $\mathbf{6 , 1 9 0 , 6 2 3}$ & $\mathbf{6 1 . 4}$ & $\mathbf{3 0 . 9}$ & $\mathbf{4 1 . 9}$ & $\mathbf{2 7 . 2}$ & $\mathbf{2 2 . 7}$ \\
\hline Haridwar & 1890422 & 18.7 & 30.6 & 36.7 & 24.7 & 19.6 \\
\hline Dehradun & 1696694 & 16.8 & 32.3 & 55.5 & 43.6 & 25.1 \\
\hline Udham Singh Nagar & 1648902 & 16.3 & 33.4 & 35.6 & 22.1 & 27.6 \\
\hline Nainital & 954605 & 9.5 & 25.1 & 38.9 & 20.8 & 18 \\
\hline HILL DISTRICTS & $\mathbf{3 , 8 9 5 , 6 6 9}$ & $\mathbf{3 8 . 6}$ & $\mathbf{3 . 6}$ & $\mathbf{1 1 . 7}$ & $\mathbf{2 . 2}$ & $\mathbf{1 . 8}$ \\
\hline Champawat & 259648 & 2.6 & 15.6 & 14.8 & 2.4 & 16 \\
\hline Almora & 622506 & 6.2 & -1.3 & 10 & 1.4 & -2.8 \\
\hline Tehri & 618931 & 6.1 & 2.3 & 11.3 & 1.9 & 0.7 \\
\hline Pauri & 687271 & 6.8 & -1.4 & 16.4 & 3.8 & -5.4 \\
\hline Pithorgarh & 483439 & 4.8 & 4.6 & 14.4 & 2.4 & 2.8 \\
\hline Chamoli & 391605 & 3.9 & 5.7 & 15.2 & 2.7 & 3.9 \\
\hline Bageshwar & 259898 & 2.6 & 4.2 & 3.5 & 0.5 & 3.8 \\
\hline Uttarkashi & 330086 & 3.3 & 11.9 & 7.4 & 0.5 & 12.4 \\
\hline Rudraprayag & 242285 & 2.4 & 6.5 & 4.1 & 3.2 & 3.4 \\
\hline UTTARAKHAND & $\mathbf{1 0 , 0 8 6 , 2 9 2}$ & $\mathbf{1 0 0}$ & $\mathbf{1 8 . 8}$ & $\mathbf{3 0 . 2}$ & $\mathbf{1 3 . 8}$ & $\mathbf{1 1 . 5}$ \\
\hline
\end{tabular}

Table 2: Population changes in Uttarakhand between 2001 and 2011.

Overall, although 70 percent of Uttarakhand's population lives in rural areas, the state is urbanizing, with the share of its urban population increasing from 26 to 30 percent between 2001 and 2011 [1]. This has corresponded with rapid growth in the state's economy: between 2005 and 2012, the Gross State Domestic Product (GSDP) grew at an average rate of 12.3 percent, compared to the 8 percent national average [2]. Consequently, the share of poor people in Uttarakhand fell from 32 percent in 2004-05 to 11 percent in 2011-12 [5,6].

\section{Gender}

There are significant variations in Uttarakhand's gender distribution, both across districts and between urban and rural areas. According to the 2011 census, there are 962 females per 1000 men in Uttarakhand. There are relatively more women in Uttarakhand's rural areas: the gender ratio in rural areas is 1000, compared to 884 in urban areas. Similarly, there are relatively more women living in the hill districts: the gender ratio in the hills is 1064 and in the plains it is 905. (Table 3) Presents changes in the gender ratio of districts in Uttarakhand between 2001 and 2011. Since 2001, the gender ratio has risen in the plains, with improvements being driven by changes in urban areas. In the hills, while there are relatively fewer women in urban areas, the gender ratio has improved significantly since 2001. There remains an overrepresentation of women in rural areas of the hills but this has also improved since $2001[3,4]$.

\begin{tabular}{|c|c|c|c|c|c|c|}
\hline \multirow{2}{*}{ DISTRICTS } & \multicolumn{2}{|c|}{ Gender ratio } & \multicolumn{2}{c|}{ Urban ratio } & \multicolumn{2}{c|}{ Rural ratio } \\
\cline { 2 - 7 } & $\mathbf{2 0 0 1}$ & $\mathbf{2 0 1 1}$ & $\mathbf{2 0 0 1}$ & $\mathbf{2 0 1 1}$ & $\mathbf{2 0 0 1}$ & $\mathbf{2 0 1 1}$ \\
\hline PLAIN DISTRICTS & $\mathbf{8 8 7}$ & $\mathbf{9 0 5}$ & $\mathbf{8 6 3}$ & $\mathbf{8 8 8}$ & $\mathbf{9 0 2}$ & $\mathbf{9 1 7}$ \\
\hline Haridwar & 865 & 880 & 844 & 866 & 874 & 889 \\
\hline Dehradun & 887 & 902 & 863 & 886 & 914 & 921 \\
\hline Udham Singh Nagar & 902 & 920 & 876 & 903 & 916 & 930 \\
\hline Nainital & 906 & 934 & 878 & 912 & 922 & 948 \\
\hline
\end{tabular}




\begin{tabular}{|c|c|c|c|c|c|c|}
\hline HILL DISTRICTS & $\mathbf{1 0 6 6}$ & $\mathbf{1 0 6 4}$ & $\mathbf{7 6 1}$ & $\mathbf{8 5 9}$ & $\mathbf{1 1 0 7}$ & $\mathbf{1 0 9 4}$ \\
\hline Champawat & 1021 & 980 & 849 & 890 & 1055 & 997 \\
\hline Almora & 1146 & 1139 & 774 & 848 & 1189 & 1177 \\
\hline Tehri & 1049 & 1077 & 628 & 817 & 1109 & 1116 \\
\hline Pauri & 1106 & 1103 & 821 & 917 & 1155 & 1144 \\
\hline Pithorgarh & 1031 & 1020 & 824 & 913 & 1066 & 1039 \\
\hline Chamoli & 1016 & 1019 & 716 & 767 & 1073 & 1072 \\
\hline Bageshwar & 1105 & 1090 & 810 & 927 & 1116 & 1097 \\
\hline Uttarkashi & 941 & 958 & 726 & 838 & 961 & 968 \\
\hline Rudraprayag & 1115 & 1114 & 444 & 697 & 1127 & 1137 \\
\hline UTTARAKHAND & $\mathbf{9 6 2}$ & $\mathbf{9 6 3}$ & $\mathbf{8 4 5}$ & $\mathbf{8 8 4}$ & $\mathbf{1 0 0 7}$ & $\mathbf{1 0 0 0}$ \\
\hline
\end{tabular}

Table 3: Changes in gender ratios in Uttarakhand between 2001 and 2011.

\section{Migration}

Migration plays an important role in the demographic changes witnessed in Uttarakhand. Women who migrate for familial reasons and young, educated men form the largest share of migrants from Uttarakhand's hill districts $[7,8]$. Studies indicate that while seasonal and cyclical migration from the hill districts is a historical process with records going back to the early 19th century in recent decades it has become largely permanent in nature $[8,9]$. A qualitative study conducted in three hill district in 2009 revealed that the main factors motivating migration are: insufficient non-agricultural employment opportunities in rural and semi-urban areas; declining agricultural productivity; the subdivision of landholdings due to increases in family size; poor infrastructure (power, water supply, roads and transport); inadequate services (education, health and market facilities); and aspirations to live in an urban environment [8].

Uttarakhand's Annual Economic Plan for 2013-14 acknowledges that migration out of the hills is primarily motivated by a lack of economic opportunities. Although the state's economy has grown rapidly since 2001 and its per-capita income has exceeded the national average since 2006, this growth has been driven by an expansion of its non-agricultural sectors. Thus, the urbanized districts in the plains have benefited most from it. In 2009, the incomes of the nine hill districts were lower than the state average, whereas the incomes of the four plain districts exceeded the state average by ten percent or more [2]. Low levels of income result in low levels of infrastructural development, which restricts the growth of employment opportunities [7]. It is believed that men are leaving the hill districts to work in the growing services and manufacturing industries in Uttarakhand's plains and other parts of India [8].

\section{Health Profile}

\section{Maternal and Child Health (MCH)}

There have been few substantial changes in $\mathrm{MCH}$ outcomes in Uttarakhand over the past decade. The infant mortality rate registered only a minor decline between 2005-06 and 2015-16, from 42 to 40 deaths per 1000 live births. (Table 4) lists changes that have occurred in other important MCH indicators over this period. Although the various surveys are not strictly comparable due to differences in sample sizes and methodologies, the data indicate that that the pace of improvements in health outcomes has been slow. Apart from the tremendous increase in institutional deliveries over the past decade, most health indicators remain low. For instance, according to the National Family Health Survey 2015-16 (NFHS-4), only 58 percent of children in the state are fully immunized [10]. While child immunization rates are similar among urban and rural populations, there are stark differences with regards to other indicators. For instance, only 9 percent of pregnant women in rural areas receive full ante-natal care (at least 3 ANC checkups, at least 2 tetanus toxoid injections and consumed at least 100 Iron Folic Acid tablets), compared to 16 percent of women in urban areas. Similarly, 64 percent of deliveries in rural areas take place in medical institutions, compared to 79 percent of births in urban areas. 
Public Health Open Access

\begin{tabular}{|c|c|c|c|c|c|c|c|}
\hline \multirow{2}{*}{ Indicator } & \multirow{2}{*}{$\begin{array}{c}\text { 2005-06 } \\
\text { Total } \\
\end{array}$} & \multicolumn{2}{|c|}{2009} & \multicolumn{2}{|c|}{2012} & \multicolumn{2}{|c|}{ 2015-16 } \\
\hline & & Rural & Total & Rural & Total & Rural & Total \\
\hline \multicolumn{8}{|c|}{ Antenatal care* } \\
\hline Received at least 3 ANC checkups & - & 46.7 & 54.8 & 52.6 & 58.9 & - & - \\
\hline Received at least 4 ANC checkups & 34.9 & - & - & - & - & 25.7 & 30.9 \\
\hline $\begin{array}{c}\text { Consumed IFA tablets/ syrups } \\
\text { for } 100+\text { days }\end{array}$ & 16.4 & 13.3 & 19.4 & 18.4 & 21.4 & 23.8 & 24.9 \\
\hline $\begin{array}{c}\text { Births protected against neonatal } \\
\text { tetanus }^{\dagger}\end{array}$ & 68.5 & 82.2 & 84.9 & - & - & 90.4 & 91.4 \\
\hline \multicolumn{8}{|c|}{ Births* } \\
\hline Institutional deliveries & 32.6 & 45 & 53.5 & 52.1 & 58.3 & 63.7 & 68.6 \\
\hline $\begin{array}{l}\text { Institutional deliveries at public } \\
\text { institutions }\end{array}$ & 48.2 & 72 & 62.2 & 71.4 & 64.8 & 69.9 & 63.8 \\
\hline \multicolumn{8}{|c|}{ Immunizations (for children 12-23 months old) } \\
\hline $\begin{array}{l}\text { Received at least } 1 \text { doze of vit A } \\
\text { in past } 6 \text { months } \neq\end{array}$ & 12.8 & - & 59.6 & 56.3 & 57.1 & 36.9 & 36.9 \\
\hline No vaccinations received & - & 9.7 & 9.1 & 5.2 & 4.9 & - & - \\
\hline Fully immunized $\S$ & 60 & 70.3 & 71.5 & 78.1 & 79.6 & 58.2 & 57.7 \\
\hline $\begin{array}{l}\text { Partially or fully immunized } \\
\text { children who received most } \\
\text { vaccinations in a public facility } \|\end{array}$ & 81.7 & 95.3 & 87 & - & - & 92.4 & 91 \\
\hline \multicolumn{8}{|c|}{$\begin{array}{c}\text { * For births occurring } 12 \text { months preceding the survey or in } 2011 \text { (AHS) † Includes mothers who received at least two } \\
\text { injections during the pregnancy of her last birth ₹ For children 6-35 months old for 2012, 9-59 months old for 2005- } \\
06,2015-16 \S \text { BCG, measles, and } 3 \text { doses each of polio and DPT || Govt. / municipal hospital, PHC, CHC, sub centre or } \\
\text { anganwadi centre }\end{array}$} \\
\hline
\end{tabular}

Table 4: Health indicators and outcomes in Uttarakhand, 2005-2016

(Table 5) lists district level data on MCH indicators. It suggests that improvements in the delivery of health services have remained slow in most districts of Uttarakhand. Information on institutional deliveries highlights the predominance of the public sector in providing maternal and child health services. It also points towards the concentration of private health providers in the plains. This has been commented on by Uttarakhand's health department [13]. While 47 percent of institutional deliveries in urban areas occur in private facilities, 30 percent of institutional deliveries in rural areas do so. Similarly, 5 percent of children in rural areas receive their vaccinations from private providers, compared to 10 percent of children in urban areas [10].

\begin{tabular}{|c|c|c|c|c|}
\hline Districts & $\begin{array}{c}\text { Pregnant women } \\
\text { receiving at least 4 } \\
\text { ANC checkups }\end{array}$ & $\begin{array}{c}\text { Institutional } \\
\text { deliveries }\end{array}$ & $\begin{array}{c}\text { Institutional deliveries } \\
\text { at public institutions }\end{array}$ & $\begin{array}{c}\text { Fully immunized } \\
\text { children between } \\
\text { 12-23 months old* }\end{array}$ \\
\hline PLAIN DISTRICTS & $\mathbf{3 4 . 6}$ & $\mathbf{6 9 . 7}$ & $\mathbf{5 4 . 8}$ & $\mathbf{5 5 . 6}$ \\
\hline Haridwar & 24.2 & 62.8 & 37.9 & 55.3 \\
\hline Dehradun & 47.1 & 83.7 & 59.1 & 60.7 \\
\hline Udham Singh Nagar & 26.6 & 67.5 & 58.5 & 57.4 \\
\hline Nainital & 40.4 & 64.7 & 63.7 & $\mathbf{6 4 . 5}$ \\
\hline HILL DISTRICTS & $\mathbf{2 6 . 1}$ & $\mathbf{6 6 . 6}$ & $\mathbf{8 6 . 2}$ & 68.4 \\
\hline Champawat & 29 & 73.3 & 73.8 & 60.6 \\
\hline Almora & 31.7 & 66.3 & 87.2 & 51.1 \\
\hline Tehri & 23.8 & 71.1 & 83.5 & \\
\hline
\end{tabular}




\begin{tabular}{|c|c|c|c|c|}
\hline Pauri & 36.4 & 74.5 & 80.1 & 61.2 \\
\hline Pithoragarh & 30.8 & 73 & 89.5 & 74.2 \\
\hline Chamoli & 20.3 & 53.3 & 92.7 & 62.2 \\
\hline Bageshwar & 23.4 & 55.9 & 88.7 & 60.2 \\
\hline Uttarkashi & 22.2 & 65.1 & 90.5 & 72 \\
\hline Rudraprayag & 17.2 & 66.5 & 89.9 & $\mathbf{5 7 . 7}$ \\
\hline UTTARAKHAND & $\mathbf{3 0 . 9}$ & $\mathbf{6 8 . 6}$ & $\mathbf{6 3 . 8}$ & \\
\hline \multicolumn{4}{|l}{ Source: NFHS IV (2015-16) [10] } \\
\hline
\end{tabular}

Table 5: Health services in the districts, 2015-16.

\section{Nutritional Deficiencies}

There have been significant changes in the nutritional profile of Uttarakhand's population over the past decade. Data collected by National Family Health Surveys suggest that under-nutrition among women (indicated by a Body Mass Index of less than $18.5 \mathrm{~kg} / \mathrm{m} 2$ ) reduced from 30 to 18 percent between 2005-06 and 2015-16. However, this period also witnessed a rise in the proportion of overweight or obese women; their share in the population was 20 percent in 2015-16. Among men, 16 percent were found to be underweight and 18 percent are obese or overweight. Anaemia remains a significant problem: 60 percent of children between the ages of six and 59 months, and 45 percent of women were found to be anaemic in 2015-16 [10].

\section{Chronic Diseases}

The Annual Health Survey conducted in 2012 provides information about the reported prevalence of chronic illnesses in Uttarakhand. Among the diseases about which information was collected, namely: arthritis, asthma diabetes, hypertension and tuberculosis (TB), arthritis is the most frequently reported illness (2019 diagnosis per 100,000 people). While diabetes, TB and asthma were more likely to be reported by men compared to women, arthritis and hypertension was more likely to be reported by women. Respondents in urban areas were more likely to report being diagnosed with hypertension, TB and diabetes, compared to respondents in rural areas. People surveyed in rural areas were relatively more likely to report a diagnosis of arthritis and/or asthma [12].

\section{Health Programs}

\section{National Rural Health Mission (NRHM)}

NRHM was launched in Uttarkhand in October 2005 to improve access to quality health services in rural and underserved areas of the state. Uttarakhand was one of 18 special focus states for the National Rural Health Mission
(NRHM) because of its weak health indicators and infrastructure [13]. Since its launch, a number of crosssectional studies and assessments have been conducted on the implementation and effects of the program. Statespecific policies and institutions regulate health programs in India, and Uttarakhand's state health society, which implements NRHM, acknowledged in 2012 that despite more than seven years of the program, health indicators were yet to show substantial improvements [14]. It listed difficulties in providing services in remote, sparsely populated areas and the shortage of health professionals as the major constraints inhibiting improvements in health outcomes. Uttarakhand faces a severe shortage of health workers. The density of doctors, dentists, nurses and midwives in the state in 2009 was 0.39 per 1000 population [15]. This is the third lowest amongst states in India and falls critically below the threshold of at least 2.28 health workers recommended by the World Health Organization in 2006 for high coverage of essential health services [16]. In 2009, the density of doctors in the state was the sixth lowest amongst states in India (0.31 per 1000 population) and the density of nurses and midwives (0.08 per 1000 people) was the lowest in the country [15].

Another study conducted in 2012 on the implementation of NRHM in Uttarakhand also highlights the problems people face in accessing health services in the state. It notes that over 58 percent of approved posts for medical officers in public health facilities are lying vacant. Similarly, 27 percent of the approved positions for Auxiliary Nurse Midwives (ANMs) and 35 percent of positions approved for Staff Nurses are yet to be filled. In addition, in most public health facilities deliveries are conducted by community health workers and nurses. Out of 18 District Hospitals (DHs) and 55 Community Health Centres (CHCs) in the state, only 11 DHs and 6 CHCs have the capacity to conduct caesarean sections and abortions in the first and second trimesters [17]. 
Rogi Kalyan Samitis (RKS, or Village Health Sanitation and Nutrition Committees) are an important component of NRHM, aimed at improving community participation in the public health system. A mixed-methods study conducted in 2009 in the districts of Nainital and Udham Singh Nagar found that although such committees were functioning in the surveyed blocks, RKS members who weren't health personnel were not actively involved in decision-making and lacked clarity on their rights and responsibilities [18]. Similar findings were echoed by another study on the functioning of committees in two blocks of Nainital in 2012-13 [19].

In order to improve access to family planning and reproductive health services in hard-to-reach villages, the government of Uttarakhand introduced Mobile Health Vans (MHV) in 2009, in part relying on NRHM funds to do so $[20,21]$. Following a USAID supported pilot program, at least two vans with expanded medical capacities were provided to each of the state's thirteen districts. From 2010 to 2011, about 5000 camps were held by health personnel working in these vans and they provided medical and diagnostic services to approximately 300000 people, either free of cost or in exchange for a subsidized user fee. An internal assessment of the expanded MHV program in 2011 found that it faced a number of problems, such as the absence of active monitoring by district health officials. Following these findings, steps were taken to improve the functioning of the program [20]. However, an external assessment conducted in 2013 found the program battling the same challenges that had been reported earlier, with no details on improvements in the program over time [22].

\section{Rashtriya Swastha Bima Yojana (RSBY)}

RSBY was introduced in Uttarakhand in 2008 to provide health insurance to poor families living below the state's designated poverty line. It is designed to cover hospitalization related expenses for a range of surgical and nonsurgical procedures performed at empanelled public and private hospitals. One RSBY card provides 30,000 INR (approximately 500 USD) worth of annual coverage for a family of five [23]. Although no studies have been conducted on the impact of RSBY on healthcare expenditures in Uttarakhand, a number of national and state-level studies suggest that RSBY has not been successful in providing significant financial protection for inpatient care. For example, in their nationwide impact assessment of RSBY, Karan et al. found that while the scheme funded about 5.8 million hospitalizations between 2008 and 2013, the covered population of approximately 130 million persons enrolled in the program during this period should have experienced 26.2 million hospitalizations annually. RSBY was also found to have an insignificant impact on out-of-pocket expenditures [24]. Data available for Uttarakhand suggests a similar scenario for the state. As table 6 shows, few eligible families in Uttarakhand have enrolled in the RSBY program-the state's enrolment ratio is less than 50 percent-and a very small number of hospitalizations have been covered by the scheme.

The difficulties associated with implementing and expanding RSBY in Uttarkhand, especially in the hill districts, could be linked to the challenged faced by other health programs in the region. First, the inability of public hospitals to provide care due to a dearth of medical professionals could be affecting the utilization of RSBY. As (Table 6) shows, nearly 80 percent of empanelled hospitals in the hill districts are public. Based on research mentioned earlier, it is likely that these institutions do not have medical professionals to conduct all the inpatient care procedures covered under RSBY. This means that even if a patient has a valid RSBY card and needs a procedure covered by the program, many empanelled hospitals will not be able to provide it. Thus, people might not be benefitting from the scheme because of problems related to the supply of public health services. On the other hand, private hospitals are harder and more expensive to reach than public hospitals because they are concentrated in urban areas and plain districts. In addition, studies in other parts of India have highlighted cases in which private hospitals refuse to admit RSBY patients due to administrative concerns that the cost of treatment will not be reimbursed by the government [2628]. The same might be happening in Uttarakhand. Furthermore, as has been noted in studies conducted in other states, it is possible that the medical procedures responsible for causing heavy out-of-pocket expenditures in Uttarakhand are not covered by RSBY [24-29]. Conversely, card-holders may not be aware of the procedures covered under the scheme. Currently, there is very little information available from Uttarakhand on the implementation and impact of RSBY. 


\begin{tabular}{|c|c|c|c|c|c|}
\hline \multirow{2}{*}{ Districts } & \multicolumn{2}{|c|}{ Target Families } & \multicolumn{2}{|c|}{ Empanelled Hospitals } & \multirow{2}{*}{$\begin{array}{c}\text { Hospitalizations from } \\
\text { Feb 1, } 2013 \text { to Sept 30, } \\
2015\end{array}$} \\
\hline & Total & Enrolled (\%) & Private & Public & \\
\hline PLAIN DISTRICTS & 315858 & 37.7 & 54 & 48 & 333 \\
\hline Haridwar & 92253 & 47 & 18 & 9 & 135 \\
\hline Dehradun & 95433 & 27 & 11 & 25 & 197 \\
\hline Udham Singh Nagar & 69487 & 39.4 & 15 & 7 & - \\
\hline Nainital & 58685 & 38.4 & 10 & 7 & 1 \\
\hline HILL DISTRICTS & 403107 & 41.3 & 13 & 47 & 117 \\
\hline Champawat & 19565 & 34.3 & 1 & 3 & - \\
\hline Almora & 61599 & 36.6 & 3 & 7 & 1 \\
\hline Tehri & 62715 & 50.2 & 2 & 6 & 65 \\
\hline Pauri & 60804 & 47.1 & 3 & 9 & - \\
\hline Pithorgarh & 46905 & 45.7 & 2 & 6 & 14 \\
\hline Chamoli & 32383 & 37.8 & - & 6 & - \\
\hline Bageshwar & 26210 & 30.9 & - & 3 & - \\
\hline Uttarkashi & 67833 & 32.7 & - & 4 & 33 \\
\hline Rudraprayag & 25093 & 52 & 2 & 3 & 4 \\
\hline UTTARAKHAND & 718965 & 39.7 & 67 & 95 & 450 \\
\hline \multicolumn{6}{|c|}{ Source: RSBY website[25] } \\
\hline
\end{tabular}

Table 6: The RSBY program in Uttarakhand, 2015.

\section{Conclusion}

This study sheds light on the challenges Uttarakhand faces in improving access to public health services. Given the concentration and continued movement of the population and resources to the plain districts, the state seems to be confronted with the need to design different programs for plain and hill areas. In the latter, difficulties related to the hilly terrain and transport aggravates their remoteness and makes it difficult to monitor health programs. Based on our review of the literature on NRHM and RSBY in Uttarakhand, it is clear that there is scant information available on the implementation of these programs and people's experience with them. Currently available research seems to be restricted to particular districts, with no information available on whether the challenges faced in implementing health programs vary across districts and socio-cultural and political contexts. Moving forward, it is imperative for state and non-state agencies to invest in research that sheds light on the implementation of health program. For this purpose, linking research efforts with program monitoring arrangements is an avenue worth exploring.

\section{References}

1. Government of India. Census of India (2011) New Delhi: Office of the Registrar General and Censes Commissioner, Ministry of Home Affairs.
2. Government of Uttarakhand. Annual State Plan 201314. New Delhi: Planning Commission; 2013.

3. ENVIS Center on Himalayan Ecology. District-wise population of Uttarakhand, Census 2001. Almora: G.B. Pant Institute of Himalayan Environment and Development. Date accessed May 12, 2016.

4. Government of India. Census of India district census handbooks: village and town wise primary census abstract (PCA) (2011) New Delhi: Office of the Registrar General and Censes Commissioner, Ministry of Home Affairs; 2011.

5. Government of India. Press Note on Poverty Estimates 2004-05. New Delhi: Planning Commission; 2007.

6. Government of India. Press Note on Poverty Estimates 2011-12. New Delhi: Planning Commission; 2013.

7. Mittal S, Tripathi G, Sethi D (2008) Development strategy for the hill districts of Uttarakhand. ICRIER working paper 217. New Delhi: Indian Council for Research on International Economic Relations.

8. Jain A (2010) Labour migration and remittances in Uttarakhand. 
9. Pathak S (1997) State, society and national resources in Himalaya: dynamics of change in colonial and postcolonial Uttarakhand. Economic and Political Weekly 32: 17 .

10. International Institute for Population Science. National Family Health Survey-4, 2015-16. Mumbai 2016.

11. UNICEF Coverage Evaluation Survey (2009) Fact Sheets.

12. Government of India. Annual Health Survey 2012-13 Fact sheet- Uttarakhand. New Delhi: Office of the Registrar General and Censes Commissioner, Ministry of Home Affairs 2014.

13. Uttarakhand health and family welfare society.

14. Joe W, Sharma S, Alam M (2012) Monitoring of important components of state PIP 2012-13. New Delhi: Institute of economic growth.

15. Hazarika I (2013) Health workforce in India: assessment of availability, production and distribution. WHO South-East Asia Journal of Public Health 2(2): 106-112.

16. World Health Organization (2006) The world health report 2006 - Working together for health.

17. Government of India (2014) Rural Health Statistics 2013-14. New Delhi: Ministry of Health and Family Welfare Statistics Division, Government of India.

18. Nandan D, Rawat CMS, Pandey SA (2009) Rapid Appraisal of Functioning of Rogi Kalyan Samiti in the Districts of Nainital and Udham Singh Nagar, Uttarakhand. Department of Community Medicine, UFHT Medical College, Haldwani 2008-09.

19. Semwal V, Jha SK, Rawat CMS, Kumar S, Kaur A (2013) Assessment of village health sanitation and nutrition committee under NRHM in Nainital district of Uttarakhand. Indian Journal of Community Health 25: 4 .
20. IFPS Technical Assistance Project (ITAP) (2012) Reaching Underserved Communities through Mobile Health Vans In Uttarakhand, India.

21. Roy D, Kakkar R, Kandpal SD (2012) Trends in utilization of mobile health services, morbidity pattern and health seeking in Uttarakhand. Indian Journal of Community Health 24: 4.

22. Sood AK, Singh G, Shehrawat R (2013) Evaluation of mobile medical units (MMUs) in Uttarakhand. National Institute of Health and Family Welfare.

23. Uttarakhand health and family welfare society. Rashtra Swastha Bima Yojana.

24. Karan A, Yip W, Mahal A (2017) Extending health insurance to the poor in India: An impact evaluation of Rashtriya Swasthya Bima Yojana on out of pocket spending for healthcare. Soc Sci Med 181: 83-92.

25. Rashtra Swastha Bima Yojana Scheme Status.

26. Rajasekhar D, Berg E, GhatakM, Manjula R, Roy S (2011) Implementing health insurance: The rollout of Rashtriya Swasthya Bima Yojana in Karnataka. Economic and Political Weekly 46(20): 56-63.

27. Devadasan N, Seshadri T, Trivedi M, Criel B (2013) Promoting universal financial protection: evidence from the Rashtriya Swasthya Bima Yojana (RSBY) in Gujarat, India. Health Res Policy syst 11: 29.

28. Karpagam S, Vasan A, Seethappa V (2016) Falling through the gaps: women accessing care under Health Insurance schemes in Karnataka. Indian journal of gender studies 23(1): 69-86.

29. Nandi S, Dasgupta R, Garg S, Sahu S, Mahobe R, et al. (2016) Uncovering coverage: utilization of universal health insurance scheme, Chhatisgarh by women in slums of Raipur. Indian journal of gender studies 23(1): 43-68. 